Mercator, Fortaleza, v. 16, e16007, 2017.

DOI: https://doi.org/10.4215/rm2017.e16007

ISSN: 1984-2201

Copyright @ 2002, Universidade Federal do Ceará

\title{
A CRITIQUE OF THE PRINCIPLES FOR RESPONSIBLE AGRICULTURAL INVESTMENT
}

(a) Msc in Engineering, Federal University of Santa Maria (UFSM). http://lattes.cnpq.br/7163349202834820

\section{(*) CORRESPONDING AUTHOR}

Address: Universidade Federal de Santa Maria - Camobi, CEP: 97105900, Santa Maria (RS), Brasil. Tel: (+55 55) 32208333. E-mail: castellanelli@bol.com.br

\section{CASTELLANELLI, Carlo Alessandro a *}

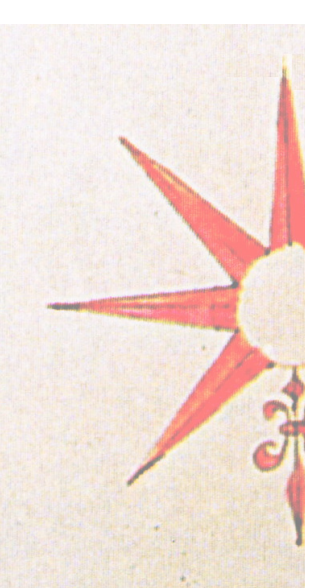

\begin{abstract}
The CFS (Committee on World Food Security) principles provide a framework to help ensure that investment in agriculture is sustainable, and contributes to inclusive growth and poverty reduction. This paper analyzes the recent phenomenon known as land grabbing as an important topic for theoretical and empirical investigations. Initially, it focuses on discussions of the existing literature on the subject, building on empirical data from previous studies, and then addresses the impacts of land negotiations around the world. Subsequently, there is a systemic examination of the CSF principles. This critical analysis demonstrates that the protection against land grabbing is weak and there is an urgent need for clearer and more precise frameworks. Finally, this analysis shows that a deeper understanding of contemporary globalization is needed with respect to the governance aspects within the complex schemes of investment in foreign lands.
\end{abstract}

Keywords: Land Grabbing; Food Security; Biofuels; Social and Environmental Impacts.

\section{RESUMO/ RESUMEN}

\section{CRÍTICA AOS PRINCÍPIOS PARA INVESTIMENTO RESPONSÁVEL EM AGRICULTURA}

Os princípos do CFS (Comitê de Segurança Alimentar Mundial) fornecem diretrizes para ajudar a garantir investimento sustentável na agricultura e a contribuir ao crescimento da inclusão social e da redução da pobreza. Este artigo analisa o crescimento do fenômeno land grabbing como um importante tópico para investigações teóricas e empíricas. Inicialmentre foca em debates da literartura existente sobre o assunto, avançando em dados empíricos de estudos anteriores para, em seguida, abordar os impactos das negociações de terras pelo mundo. Subsequentemente, examina os princípios da CSF de forma sistêmica. Essa análise demonstrou fraca proteção ao fenômeno do land grabbing e necessidade urgente de frameworks mais claros e precisos. Por fim, mostra que é necessário maior entendimento da globalização contemporânea no que tange aos aspectos de governança dentro do complexo esquema de investimento em terras estrangeiras.

Palavras-chave: Grilagem; Segurança Alimentar; Biocombustíveis; Impactos Sócio-Ambientais.

\section{CRÍTICA A LOS PRINCIPIOS PARA LA INVERSIÓN RESPONSABLE EN SISTEMAS AGRÍCOLAS}

Los Principios de la CFS (Comité de Seguridad Alimentaria Mundial) proporcionan directrices para ayudar a asegurar que la inversión en la agricultura es sostenible y que contribuyan para la inclusión social y la reducción de la pobreza. Este trabajo analiza lo reciente fenómeno llamado acaparamiento de tierras como un tema importante para las investigaciones teóricas y empíricas. Inicialmente, se centra en las discusiones de la literatura existente sobre el tema, avanzando en los datos empíricos de los estudios anteriores, a continuación, hace frente a los impactos de las negociaciones de la tierra en todo el mundo. Después, examina los principios de lo CFS de una manera sistémica, proporcionando un análisis crítico, que demostra que hay una débil protección al fenómeno de acaparamiento de tierras y una necesidad urgente de frameworks más claros. Por último, este análisis muestra que se necesita una comprensión más profunda de la globalización contemporánea con respecto a los aspectos de gobernancia dentro del complejo esquema de inversión en tierras extranjeras.

Palabras clave: Acaparamiento de tierras; Seguridad alimentaria; Biocombustibles; Impactos Sociales y ambientales. 


\section{INTRODUCTION}

Private investment in the agricultural sector, including from foreign sources, offers significant potential to complement public resources. Many countries with adequately functioning markets have derived significant benefits from this investment in terms of better access to capital, technology and skills, employment generation, and productivity increases. In addition to establishing farms and plantations themselves, some large investors have achieved broad-based benefits via contract farming, other outgrower arrangements, and joint ventures with local communities. This often involves formulating innovative schemes for sharing both risks and rewards.

On the other hand, according to the FAO - Food and Agriculture Organization of the United Nations (2014), where rights are not well defined, governance is weak or those affected lack a voice, there is evidence that such investment can carry considerable risks of different types. These risks include the displacement of local populations, the undermining or negation of existing rights, increased corruption, reduced food security, environmental damage in the project area and beyond, the loss of livelihoods or opportunities for land access by the vulnerable, nutritional deprivation, social polarization and political instability. Moreover, in the past many large farming investments have proven unsuccessful.

Proponents of large-scale land acquisitions argue that poor countries could benefit from direct foreign investment in land (World Bank 2011), while opponents argue that large scale land acquisition is nothing more than neo-colonial theft of poor peasants' livelihoods, known as land grabbing (Borras and Franco, 2010).

In 2010, the FAO, IFAD (International Fund for Agricultural Development), the UNCTAD (UN Conference on Trade and Development) Secretariat and the World Bank Group joined together through the CFS (Committee on World Food Security) to propose the Principles for Responsible Agricultural Investment that Respects Rights, Livelihoods and Resources. The document concluded by anticipating the next steps, pointing toward a toolkit of best practices, guidelines, governance frameworks, and possibly codes of practice for the main groups of private actors.

In 2014, there was another discussion and a new guide emerged. The Principles for Responsible Investment in Agriculture and Food Systems were approved by the 41st Session of the CFS on 15 October 2014. The new Principles were developed by an Open Ended Working Group over the course of October 2012 - October 2014. They are based on an inclusive process of consultations that occurred from November 2013 - March 2014. Regional consultations and workshops were held in Africa, Europe and Central Asia, North America, Asia and the Pacific, Latin America and the Caribbean, and the Near East. The Principles also included feedback received through an electronic consultation. The consultations included governments, UN agencies, civil society and non-governmental organizations, international agricultural research institutions, private sector associations and private philanthropic foundations, international and regional financial institutions. The objective of the Principles was to promote responsible investment in agriculture and food systems that contribute to food security and nutrition, thus supporting the progressive realization of the right to adequate food in the context of national food security.

However, land deals are having a devastating impact on some of the world's poorest and most vulnerable communities that depend on their land for survival. Most deals are taking place in countries with serious hunger problems, yet the majority of crops grown on land from these deals are intended for export. Transactions are usually done in secrecy, without the free, prior and informed consent of impacted communities. Despite the devastating impact on local people, governments are aggressively pursuing foreign investors with promises of free or cheap land, cut-rate loans and generous tax incentives including tax exemptions.

This paper aims to discuss the protection against the global phenomenon known as Land Grabbing, through the protection of control mechanisms such as the CSF principles. 


\section{THE EMERGING PHENOMENON OF LAND GRABBING}

The various aspects of the global crisis (financial, environmental, energetic and food) in recent years have contributed to a dramatic urgency for the control of land, especially land located in the southern hemisphere. National and transnational economic actors from various business sectors such as oil, mining, energy, food, among others, are acquiring or intend to acquire land to maintain or expand their industries.

The governments of countries that are rich in funds and poor in resources are seeking territory in countries that are rich in resources and poor in funds to help meet their food and energy needs in the future. At present, the issue relates to strong dynamics among which the accelerated technological modernization processes and their impact on the rural production structure are noteworthy. Today, there are concerns related to different challenges with climate change, food security and financial problems.

A World Bank study shows that the growth of global agricultural production and consequently the demands on land purchase transactions focuses on the expansion of only eight commodities: corn, palm, rice, canola, soybeans, sunflower, sugar cane and maize (TWB, 2011). The high prices of biofuels and government subsidies have led to expansion of these crops. In 2008, the estimate was that 36 million hectares of the total area was cultivated with raw material for biofuels, an area twice as large as in 2004 (TWB, 2011). According to Borras and Franco (2012), these commodities are mainly responsible for foreign investments in countries like Brazil, but also in other Latin America countries. Increased foreign ownership and the (re) concentration of land and capital go beyond food production, with a special emphasis on biofuels, mining and wood. The narrative of the race of the growing demand for food (Borras and Franco, 2012) and the interest in land is associated with biofuel production projects and other agricultural and non-agricultural commodities, attracting capital from various sectors, including investment funds (TWB, 2011).

One of the factors identified by the World Bank is speculative investments, which combined with productive investments, causing a winning process through land rent. The combination of price (the lower cost of land in border areas), the absence of taxes and government investment in infrastructure construction are key elements in speculative processes, transforming land into a financial asset (LEITE; SAUER, 2011). A significant factor in the World Bank report is the characterization of potential claimants of land. According to the report there are three types at the moment:

a) Governments concerned about domestic demand and their inability to produce enough food for the population, especially since the food crisis in 2008, generated by rising prices;

b) Financial companies that foresee advantages in land acquisition;

c) Sector companies (agro-industrial and agribusiness) that seek to expand their business due to the high level of trade and processing concentration (TWB, 2011).

Although not directly addressing the issue, when discussing "green grabbing" Fairhead et al. (2012) portray this subject, including "land alienation processes" in the context of "accumulation by dispossession". The central theme, as already mentioned, is the land grab for food and biofuels, in a neoliberal logic of land use (Fairhead et al., 2012). Consequently, today the land issue in the twenty-first century is not restricted to political disputes, as part of an unresolved social problem (rural poverty) (Martins, 2000) in countries like Brazil, instead there is growing interest worldwide for agricultural and non-agricultural commodities (COTULA et al, 2008; BORRAS and FRANCO 2012). Although Oliveira (2010) points out that this is not a new issue some studies point to a global land rush. 
The large-scale use of conservation crops for biofuel production purposes, among others, receives the name of pro-environmental land grabbing; a kind of land grabbing in the name of the environment. There is a growing consensus that the phenomena of concentration and "foreignization" of land places some issues in various dimensions: political, economic, environmental and social.

In addition to social issues, the resulting environmental dimension of an act with a purely productive bias and profit maximization, can lead to intensive soil use and water contamination with pesticides and other environmental impacts. The absence of a regulatory framework regarding the use and purchase of land can lead to a scenario of no socio-environmental sustainability.

Borras and Franco (2010), demonstrate that Brazil and Argentina are the South America countries with the highest incidence of land grabbing. They observed a common trend between the two countries, namely, a weak governance structure.

In October 2008, the GRAIN website (an international nonprofit organization that works to support peasants, small farmers and social movements in their struggles to achieve communally controlled food systems based on biodiversity) began to publish news and articles related to land grabbing worldwide by global companies, particularly those operating in the food trade and investment funds and private investors (www.grain.org). They even created a specific website to report news regarding the ownership of land by foreigners. (http://farmlandgrab.org/).

Thus, GRAIN (2011) was the first to report the scheme of the acquisition of land by foreigners around the world: the current food and financial crises combined, triggering a new global land grab cycle. Governments that face food insecurity and which rely on imports to feed their populations are rapidly taking over agricultural land around the world, where they produce their own food outside of their country of origin. Global corporations that sell food and private investors, hungry for profits amid the deepening financial crisis, see investment in foreign farmland as an important new source of profit. As a result, fertile agricultural lands are privatized and increasingly concentrated.

GRAIN went beyond this statement. The text also identified, without a shadow of a doubt, the end of peasant agriculture and the countryside for a living. Faced with the inability to stop this process, in many parts of the world the appropriation of global land could mean the end of small-scale agriculture.

Regarding the process of acquisition and leasing of land by foreigners, Oliveira (2010) explains that texts in English began to use various notions/concepts: farmland grab; land grab (AREZKI, DEININGER and SELOD, 2010; KUGELMAN and LEVENSTEIN, 2010); land grabbing (BRAUN, von J., and R. MEINZEN-DICK 2009; FIAN 2010; LEITE and SAUER 2008). Lee Mackey (2011), researcher of the Department of Planning, University of California, Los Angeles uses the notion of the "foreignization" of space, and there also the notion of the "foreignization" of land (MACKEY, 2011).

As Merlet (2010), remembers correctly, this process cannot be reduced merely to the mechanism of the purchase of land, which requires the operation of a land market marked by the purchase and sale of farms. According to the study requested by the Committee Technique - Foncier et Développement, we are facing the appropriation and concentration of land and natural resources on a large scale (MERLET, 2010).

\section{ARE THE CSF'S PRINCIPLES RELIABLE?}

The Principles address all types of investment in agriculture and food systems - public, private, large, small - and in the production and processing spheres. They provide a framework that all stakeholders can use when developing national policies, programs, regulatory frameworks, corporate social responsibility programs, individual agreements and contracts. They are voluntary and non-binding, but represent the first time that governments, the private sector, civil society orga- 
nizations, UN agencies, development banks, foundations, research institutions and academia have agreed on what constitutes responsible investment in agriculture and food systems that contribute to food security and nutrition (FAO, 2014).

According to the FAO (2014), the Principles represent the first global consensus defining how investment in agriculture and food systems can benefit those who need it the most. Now the Principles need to be translated into actions. What do the Principles mean for each stakeholder and how do we all work together to apply them and make a real difference in ensuring food security and nutrition on the ground? While the Principles provide the basis for moving forward together, the people responsible for translating global policy into action - policy makers, lawmakers, investors, farmers, processors, traders, retailers, consumers, etc. - need to think through the practical steps at all stages of food systems.

The four key dimensions of food security are availability, access, utilization and stability. The Principles are based on the following documents as the foundation for responsible investment in agriculture and food systems:

1. Universal Declaration of Human Rights - Adopted by the UN General Assembly on 10 December 1948 and human rights treaties which are binding for the respective State Parties;

2. International Labor Organization Declaration (ILO) on the Fundamental Principles and Rights at Work - Adopted by the International Labor Conference in June 1998;

3. Voluntary Guidelines on the Progressive Realization of the Right to Adequate Food in the Context of National Food Security - Adopted by the FAO in 2004;

4. United Nations Declaration on the Rights of Indigenous Peoples - Adopted by the United Nations General Assembly on 7 September 2007;

5. Guiding Principles on Business and Human Rights - Endorsed by the UN Human Rights Council on June 2011 and the ten Principles of the UN Global Compact in 2000; 6. Voluntary Guidelines on the Responsible Governance of Tenure of Land, Fisheries and Forests in the Context of National Food Security - Adopted by the CFS in May 2012;

7. Voluntary Guidelines for Securing Sustainable Small-scale Fisheries in the Context of Food Security and Poverty Eradication -Endorsed by the Committee on Fisheries at its 31 st Session in June 2014;

8. Global Strategic Framework for Food Security and Nutrition (GSF) of the CFS

9. Rio Declaration on the Environment and Development, proclaimed by the UN Conference on Environment and Development in June 1992;

10. The Outcome document of the UN Conference on Sustainable Development The Future We Want adopted by UNCSD in June 2012.

To better understand the criticism that will be developed herein the principles organized in 2010 and 2014 are shown below.

\section{PRINCIPLES FOR RESPONSIBLE AGRICULTURAL INVESTMENT THAT RESPECTS RIGHTS, LIVELIHOODS AND RESOURCES (2010)}

Principle 1: Existing rights to land and associated natural resources are recognized and respected. 
Principle 2: Investments do not jeopardize food security but rather strengthen it.

Principle 3: Processes relating to investment in agriculture are transparent, monitored, and ensure accountability by all stakeholders, within a proper business, legal, and regulatory environment.

Principle 4: All those materially affected are consulted and agreements from consultations are recorded and enforced

Principle 5: Investors ensure that projects respect the rule of law, reflect industry best practice, are viable economically, and result in durable shared value.

Principle 6: Investments generate desirable social and distributional impacts and do not increase vulnerability

Principle 7: Environmental impacts of a project are quantified and measures taken to encourage sustainable resource use, while minimizing the risk/magnitude of negative impacts and mitigating them.

\section{PRINCIPLES FOR RESPONSIBLE INVESTMENT IN AGRICULTURE AND FOOD SYSTEMS (2014)}

Principle 1: Contribute to food security and nutrition.

Principle 2: Contribute to sustainable and inclusive economic development and the eradication of poverty.

Principle 3: Foster gender equality and women's empowerment.

Principle 4: Engage and empower youth.

Principle 5: Respect the tenure of land, fisheries and forests, and access to water.

Principle 6: Conserve and sustainably manage natural resources, increase resilience, and reduce disaster risks.

Principle 7: Respect cultural heritage and traditional knowledge, and support diversity and innovation.

Principle 8: Promote safe and healthy agriculture and food systems.

Principle 9: Incorporate inclusive and transparent governance structures, processes, and grievance mechanisms.

Principle 10: Assess and address impacts and promote accountability.

These principles are presented as indicators for "responsible agricultural investment" providing a win-win solution, however, it should be taken into consideration that the principles could be used to legitimize what is unacceptable: (foreign and domestic) companies seeking to take over large amounts of land.

Responsible agricultural investments could in fact be a rationalization of land grabbing (FIAN 2010; Via Campesina 2009). These principles seem to be more concerned with ensuring a smooth transfer of existing land rights to investors, keeping farmers and communities' land in their hands now and in the future. The concept of "existing rights to land" does not include the right of the landless to re-obtain effective access to land. In most contexts, land reform, including land redistribution, is a compulsory measure under the human right to food. Reducing land resources available for redistribution and the orientation of agricultural policies in order to avoid agrarian reform is a regressive measure and therefore violates the human right to food. 
Food security assessments are usually based on official national aggregate data on supply and demand for food, regardless of who produces it, where they come from, how it is produced or who has real access, beyond the nationally aggregated data. In the end, what can happen is that some countries that produce food and fuel for trade within and outside their national borders end up importing food products from abroad.

Savaresi (2015), argues that the Principles are defined as voluntary and were not intended to add new content, but rather to synthesize existing relevant binding and non-binding international instruments. The Principles mark the difference between these two categories clearly by using three different expressions under "Roles and Responsibilities": "States should" with regard to national and international law, trade and investment agreements, on the one hand; while "States are encouraged" or "States play a key role" with reference to non-binding agreements, thereby making it more difficult to use the Principles as a means to balance the discrepancies between different areas of international law. With regards to the latter, there is a risk that previously agreed standards may be overly simplified, weakening previously agreed language and thus de-emphasizing the need to honor earlier commitments.

It is important to discuss the way that the principles make transparency more responsive to the demands of transnational corporations, such as a transparent process for land acquisition to allow a "climate of stable and efficient investment" in order to avoid insecure / unstable land transactions and informal investments.

About the principle concerning "All those materially affected are consulted, and agreements from consultations are recorded and enforced", it can be concluded that the outcome of the consultations will always be the acceptance of the investment project. The central point here is that national and transnational companies, national elites and governments have exploited, manipulated or can manipulate the principle to promote their interests in land operations.

Instead of giving priority to a model of small-scale agricultural production where women, farmers, food producers are in the center, together with agro-ecological forms of agriculture and strengthening local markets, government policies have been serving big investors and a destructive model of industrial agriculture.

Rass (2006) explains that in many developing countries and particularly in Sub-Saharan Africa, for example, the rights of land users are not properly secured. Much of the land is formally owned by the government and the land users have no property titles for the land they cultivate. Also, in many cases, a complex combination of property rights and users' rights results in a situation in which those who cultivate the land do not own it, although they may or may not be paying rent in cash or in kind or may or may not have a formal agreement with the nominal owner. This situation is the source of legal uncertainty. It also implies that land users will not have access to legal remedies and receive adequate compensation if they are evicted from the land they cultivate, for instance, after the government has agreed that foreign investors take possession of the land. It is also important to recognize other rights of land use such as grazing and gathering wood, which are often critical sources of livelihood, especially for women. The rights of pastoralists in particular are generally neglected in public debates. Yet, as dry lands constitute nearly half of the land area of sub-Saharan Africa, pastoralism is of particular importance for the continent: almost half of the total amount of about 120 million pastoralists/agro-pastoralists worldwide resides in sub-Saharan Africa, where the largest pastoral/agro-pastoral populations (seven million each) are in Sudan and Somalia, followed by Ethiopia with four million. In this context, there is a real risk that land considered 'empty' or 'idle' will be sold or leased to investors, including foreign investors, without taking into account the important services this land renders to the local population. 


\section{FINAL CONSIDERATIONS}

In John Locke's famous argument, a person mixes his labor with the natural resource and thereby makes it his property (Locke 2003). However, according to Locke, since the earth is endowed to human kind as a common good from God, one should also respect others' equal right to appropriate land. Hence, Locke's proviso that enough and as good should be left in common for others. When Locke was writing the Two Treatises in the 1680's land was considered abundant.

None of the above is to suggest that large-scale land leases or purchases cannot be beneficial for all parties - the investor, the host State, and the local population involved. Large-scale investments in farmland can work for the benefit of all the parties concerned. However, this presupposes that an appropriate institutional framework is in place - and if it is not present at the time of the investment, the arrival of large investors may in fact reduce the likelihood that it will be set up in the future. It is therefore vital that the negotiations leading to such agreements comply with a number of procedural requirements to ensure the informed participation of the local communities and therefore adequate benefit sharing. The agreements themselves should take into account the human rights which could be negatively impacted by an investment. In no circumstances should agreements to lease or cede large areas of land be allowed to trump the human rights obligations of the States concerned. It is a joint responsibility of both the host State and the investor to respect the human rights involved. Where the investor is a private entity it is the responsibility of the home State to ensure that these obligations are complied with. (De Schutter, 2009).

Large-scale land acquisition and land grabbing remains a contested issue. On the one hand, there is evidence that direct foreign investments in developing countries often cause harm to local small-scale peasants. However, such investments are also needed, as they present a genuine opportunity for development. An overview of the discussion on the subject shows two ethical issues raised by two approaches: the contested issue of a human right to land and the need for an ethics of inclusion and the determination of responsibility for land grabbing. The human right to land could be argued as being compatible with the liberal tradition based on a notion that uses the right to land to entail some kind of right of property of land, in other words, a right to land that must be respected as a human right. The second issue, that of inclusion and the need to take into account the participation of land users themselves in the process of reaching fair standards, requires an ethical approach that could allow for a dialogical perspective on moral deliberation. The responsibility for land grabbing could also include a broader, global, and even individual kind of responsibility. Following Thomas Pogge's theory of a global institutional responsibility, it becomes clear that citizens who participate in a global structure that facilitates land grabbing also become responsible, due to their upholding these very same institutions.

A strong governance scheme is necessary to respect the concentration of land and land grabbing, not only in the form of non-mandatory principles, but also to analyze the regulations of each region and country due their different social, environmental and economic aspects.

\section{BIBLIOGRAPHIC REFERENCES}

AREZKI, R.; K. DEININGER and H. SELOD. Interest in Large-Scale Land Acquisition for Agribusiness Investment: Extent and Determinants and the 'Global Land Grab. Policy Research Working Paper, World Bank, Washington, DC. 2010.

BORRAS, S. and FRANCO, J. From threat to opportunity? Problems with the Idea of a 'code of conduct' for land-grabbing. Yale Human Rights \& Development L Journal, 13(2), 507-523, 2010.

BORRAS, S. and FRANCO, J. Towards a broader view of the politics of global land grab: Rethinking land issues, reframing resistance. ICAS Working Paper Series No. 001., 2010. 
BORRAS, S. and FRANCO, J. Global land grabbing and trajectories of agrarian change: A preliminary analysis. Journal of Agrarian Change, 12(1), 34-59, 2012.

BRAUN, J. von and MEINZEN-DICK, R. Land Grabbing by Foreign Investors in Developing Countries: Risks and Opportunities. Policy Brief 13, International Food Policy Research Institute, Washington, DC, 2009. COTULA et al. Fuelling Exclusion? The Biofuels Boom and Poor People's Access to Land. IIED, London and FAO, Rome, 2008.

DE SCHUTTER, O. Promotion and protection of human rights, civil, political, economic, social and cultural rights, including the right to development-Addendum: Large-scale land acquisitions and leases: a set of minimum principles and measures to address the human rights challenge. The UN Human Rights Council. A/HRC/13/33/add.2, 2009.

FAIRHEAD, J.; M. LEACH and I. SCOONES. Green Grabs: A New Form of Appropriating Nature? Journal of Peasant Studies, 39(2), edición especial, marzo, p. 112-123, 2012.

FAO - Food and Agriculture Organization of the United Nations. Principles for Responsible Agricultural Investment that Respects Rights, Livelihoods and Resources $<$ http://www.fao.org/fileadmin/templates/est/ INTERNATIONALTRADE/FDIs/RAI_Principles_Synoptic.pdf $>, 2010$.

FAO - Food and Agriculture Organization of the United Nations. Principles for Responsible Investment in Agriculture and Food Systems, 2014.

FIAN - Food First Information and Action Network. Land Grabbing in Kenya and Mozambique: A Report on Two Research Missions and a Human Rights Analysis of Land Grabbing. FIAN, Heidelberg, 2010.

GRAIN. An analysis of the human rights-based resistance against land grabbing within the framework of food regime theory. Amsterdam, 2011.

KUGELMAN, M. and LEVENSTEIN, S.L. Land Grab? The Race for the World's Farmland. Washington, DC: Woodrow Wilson International Center for Scholars, 2010.

VIA CAMPESINA. Industrial Agrofuels Fuel Hunger and Poverty. The Via Campesina Notebooks, Jakarta, p. 40, 2009.

LOCKE, J. In Shapiro, I. (Ed.). Two treatises of Government and a letter Concerning Toleration. New Haven: Yale University Press, 2003/1960.

MACKEY, Lee. Legitimating Foreignization in Bolivia: Brazilian agriculture and the relations of conflict and consent in Santa Cruz, Bolivia. Paper presented at the International Conference on Global Land Grabbing, 6-8 April, Organised by the Land Deals Politics Initiative (LDPI) in collaboration with the Journal of Peasant Studies and hosted by the Future Agricultures Consortium at the Institute of Development Studies, University of Sussex, England, 2011.

MARTINS, J. S. Reforma agrária: o impossível diálogo sobre a história possível. Brasília, MDA/Incra, 2000. MERLET, M. Les appropriations de terres à grande échelle: analyse du phénomène et propositions d'orientations. Paris: Comité Foncier et Développement, 2010.

NIKOLA, R. Policies and Strategies to address the vulnerability of pastoralists in Sub-Saharan Africa. PPLPI (Pro-Poor Livestock Policy Initiative, FAO) Working Paper No. 37,2006, www.fao.org/ag/AGAinfo/ programmes/en/pplpi/docarc/execsumm_wp37.pdf

OLIVEIRA, A. U. A QUESTÃO DA AQUISIÇÃO DE TERRAS POR ESTRANGEIROS NO BRASIL - um retorno aos dossiês. AGRÁRIA, São Paulo, No. 12, pp. 3-113, 2010.

RASS, N. Policies and Strategies to Address the Vulnerability of Pastoralists in Sub-Saharan Africa. PPLPI Working Paper No. 37. Rome, FAO, p. 93, 2006. Available in www.fao.org/AG/AGAInfo/projects/ en/ pplpi/docarc/wp37.pdf. Acess 20/nov/2014.

SAUER, S. e LEITE, S. P. Agrarian structure, foreign land ownership, and land value in Brazil - Paper presented at the International Conference on Global Land Grabbing, 6-8 April, 2011. Organised by the Land Deals Politics Initiative (LDPI) in collaboration with the Journal of Peasant Studies and hosted by the Future Agricultures Consortium at the Institute of Development Studies, University of Sussex, England. Available in $<$ http://www.iss.nl/Menupages/Research-Networks/The-Land-Deal-Politics-Initiative-LDPI/ April-2011-IDS-Sussex2/LDPI-Conference Papers/Agrarian structure-foreign-land-ownership-and-land-value-in-Brazil>. Access 18/nov/2014. 
SAVARESI A. Principles on Responsible Investment in Agriculture and Food Systems: A (very) critical analysis. Available in http://www.benelexblog.law.ed.ac.uk/2015/05/21/principles-on-responsible-investment-in-agriculture-and-food-systems-a-very-critical-analysis/, 2015.

TWB - The World Bank. Rising global interest in farm land. Washington: World Bank, 2011. 